\title{
Participatory Selection of Potato (Solanium tuberosum L.) Varieties in the Highland Areas of Guji Zone, Southern Ethiopia
}

\author{
Arega Amdie ${ }^{1,}$, , Solomon Teshome ${ }^{2}$, Beriso Wako ${ }^{1}$ \\ ${ }^{1}$ Oromia Agricultural Research Institute, Finfine, Ethiopia \\ ${ }^{2}$ Bore Agricultural Research Center, Bore, Ethiopia
}

Email address:

aregahorti2@gmail.com (A. Amdie)

${ }^{*}$ Corresponding author

To cite this article:

Arega Amdie, Solomon Teshome, Beriso Wako. Participatory Selection of Potato (Solanium tuberosum L.) Varieties in the Highland Areas of Guji Zone, Southern Ethiopia. Advances in Bioscience and Bioengineering. Vol. 9, No. 2, 2021, pp. 48-54. doi: 10.11648/j.abb.20210902.15

Received: December 2, 2020; Accepted: April 6, 2021; Published: June 21, 2021

\begin{abstract}
Potato (Solanum tuberosum L.) is one of the most important food security and cash crop for farmers in highland parts of Ethiopia, particularly in Guji zone where it is grown by farmers and seed producers abundantly. However, in the highland areas of Guji zone an access, well adapted, résistance to late blight and high yielder potato variety is highly limited. Due to this reason, there is an urgent need to develop and replace the previous underproduction varieties that suit for the area. As a result, an experiment was conducted in the highland areas of Guji Zone at Bore on-station and three farmers' fields (Abayi kuture, Raya boda, and Bube korsa) during 2019/20 cropping season to select and recommend high yielding, and diseases résistance improved potato varieties through participatory variety selection. Six (6) improved potato varieties (Gudanie, Belete, Jalenie, Dagim, Horro, and Bubu) were used as testing crop. The treatments were arranged in randomized completed block design (RCBD) with three replications for mother trial and farmers were used as replication for baby trials. Both agronomic and farmers data were collected based on the recommended standards. Data collected from mother trail were subjected to analysis of variance where as matrix ranking was used for data collected from baby trials. The analysis of variance indicated that significant differences observed at $(\mathrm{P} \leq 0.05)$ among the tested Irish potato varieties for day to $50 \%$ emergence and flowering, stem number per hill, tuber number per hill, marketable and total tuber yield. However, non-significant difference was observed at $(\mathrm{P} \geq 0.05)$ among the varieties for days to days to $90 \%$ maturity, plant height, tuber weight and unmarketable tuber yield. The highest marketable tuber yield was $(48.17 \mathrm{t} / \mathrm{ha})$ was recorded for Belete followed by Bubu and Gudanie (35.35 and 34.3t $/ \mathrm{ha}$ ) respectively. But, the lowest marketable tuber yield (18.07t/ha) was obtained from improved Dagim variety. In other cases, farmers were allowed to evaluate the varieties using their own criteria. Accordingly, variety Bubu and Gudanie were selected by farmers due to their resistant to disease, stem number, tuber size, tuber color, tuber eye depth, number of tubers and marketability. Therefore, these two improved Irish potato varieties are selected based on agronomic data result and farmers preference and recommended for production to the highland areas of Guji zone.
\end{abstract}

Keywords: Irish Potato, Participatory Variety Selection, Improved Variety

\section{Introduction}

Potato (Solanum tuberosum L.) belonging to the family Solanaceae, is an important food and cash crop as an income sources globally [17]. Potato is native to South America [15]. It is an important tuber crop grown widely in humid tropics and used as source of carbohydrates for many people in tropical and sub-tropical areas of the world [11]. Potatoes are among the most widely-grown crop plants in the world, giving good yield under various soil and weather conditions [24]. It is the third most important food security crop in the world after rice and wheat [22].

The potential for high yield, early maturity, and excellent food value give the potato great potential for improving food security, increasing household income, and reducing poverty [13]. Yields are typically three to five times higher in 
developed nations [33]. Many factors contribute to the low yield, including frost, hail, pests, diseases [4], poor production practices and limited access to high quality seed [23].

So far, different potato varieties have been released and /or registered to satisfy the growing production demands of the farmers in the country. The crop particularly has potential for fertile and waste land where other crops could not survive, to overcome food shortage [18]. In Ethiopia, potato production could fill the gap in food supply during the hunger months of July to August before the grain crops are being harvested.

Therefore, assessment of genotype $\times$ environment (including end use) interactions answers the adaptation to the environment and end users because; it is unlikely that one of many potential new cultivars would be best in all environments and for all uses [8]. The entire variable encountered in producing a crop can be collectively called an environment, while every factor that is a part of the environment, has the potential to cause differential performance that is associated with genotype, genotype to environment interaction in potatoes [8].

The low productivity is attributed due to lack of well adapted varieties which is accepted by the farmers, unavailability and high cost of seed tubers, diseases and insect (Bereke, 199; Gebremedhin et al., 2008) and [1]. This implies that the country has suitable environmental condition; the average national yield $\left(14.176\right.$ tha $\left.^{-1}\right)$ productivity of potato during 2018/19 season [12] is very low as compared with world average of $17.16 \mathrm{t} \mathrm{ha}^{-1}[16]$. The reason is primarily due to lack of adaptable varieties for marginal ecology and use of low quality seed tubers for planting [19]. There are also many factors that can contribute directly or indirectly for low yield in Ethiopia, lack of improved technology, low attention to the crop, varieties that were released by different research centers for different agroecologies in the country and farmer's potato varieties in the country level is still unidentified.

In the highland areas of Guji zone, the production of potato is low because of lack of stable, well-adapted, high yielding, acceptable and disease resistant cultivars and limited access to the available cultivars. In addition, potato yields varied depending on season, weather conditions, cultivar, and location in the study area. Farmers as well as Seed Producer Cooperative are highly demanding better yielding and late blight resistance varieties to maximize their product, and improve the livelihood of their families. Participatory varietal selection has been proposed as an option to the problem of fitting the crop to a multitude of both target environments and users preferences [9]. Identifying farmers' needs; searching for suitable material to test with farmers; and experimentation on farmers' fields [26]. In highlands of Guji zone, the varieties that currently under production are not as much as high yielder and resistance to late blight. Therefore, to evaluate different varieties of potato crop with active involvement of farmers' is important to increase the production and productivity of potato in study area. This research was conducted with the following objectives:-

1) To evaluate potato varieties with active participation of farmers

2) To increase farmers' awareness and their access to improved potato varieties that suit them better than existing ones and,

3) To identify and select adaptable, high yielding, and late blight tolerant potato variety (ies) for highland agroecologies of Guji zone.

\section{Materials and Methods}

\subsection{Description of the Experimental Site}

The experiment was conducted at four locations (Bore onstation, and three farmers' fields) during 2019/20 cropping season to select and recommend high yielding and diseases tolerant improved Irish potato varieties through participatory variety selection. Bore Agricultural Research Center site is located at the distance of about $8 \mathrm{~km}$ north of the town of Bore in Songo Bericha 'Kebele' just on the side of the main road to Addis Ababa via Awassa town. Geographically, the experimental site is situated at the latitude of $06^{\circ} 23^{\prime} 55^{\prime \prime} \mathrm{N}$ and longitude of $38^{\circ} 35^{\prime} 5^{\prime \prime} \mathrm{E}$ at an altitude of $2728 \mathrm{~m}$ above sea level. The soil is clay in texture and strongly acidic with $\mathrm{pH}$ value of 6.02[31]. Moreover, the soil is strongly acidic with $\mathrm{pH}$ value of 5.1[3]. The traditional farming system of the area is characterized by cultivation of enset as a major crop, maize, potato, head cabbage, barley, wheat and faba bean. As far as fruit and timber crops are concerned, apple and bamboo are the cash crops. Moreover, cattle are an integral part of the farming system [7].

\subsection{Treatments and Experimental Design}

About six (6) improved Irish potato varieties (Gudanie, Belete, Jalenie, Dagim, Horro and Bubu) were used as testing crop. The varieties were brought from Holeta, Adet and Bako Agricultural Research Center and Haramaya University. The treatments were arranged in randomized completed block design with three replications for mother trial (Bore onstation) and three farmers' fields were used as replication for baby trials. For this purpose, one farmer field was used as replication for baby trials in which selected farmer's plant materials in one replication and the other host farmers were planted the two non-replicated trials. At both trial sites, the materials were planted on a plot size of, $3 \mathrm{~m}$ length and $2.4 \mathrm{~m}$ width $=7.2 \mathrm{~m}^{2}$ having 4 rows with 75 and $30 \mathrm{~cm}$ between rows and plants. In puts (seeds, fertilizers) and management practices were applied as recommended for Irish potato production. Data were collected in two ways: agronomic data and farmer's data. For agronomic data phenological, Growth, yield and yield components were collected following their own principles. At vegetative and harvest stage of potato the training were arranged. 
Table 1. Description of experimental materials improved potato varieties for highland agro-ecologies of Guji zone.

\begin{tabular}{lllll}
\hline No. & Variety & Breeder & Released year & Recommended Altitude (masl) \\
\hline 1. & Gudanie & Holeta research centre & 2006 & $1600-2800$ \\
2. & Jalenie & Holeta research centre & 2002 & $1600-2800$ \\
3. & Dagim & Adet research centre & 2013 & $1600-2800$ \\
5. & Horro & Bako research centre & 2015 & $2000-2800$ \\
6. & Belete & Holeta research centre & 2009 & $1600-2800$ \\
7. & Bubu & Haramaya University & 2011 & $1700-2000$ \\
\hline
\end{tabular}

Source: MoANR (2017)[27]

\subsection{Field Management}

The experimental field was cultivated by using oxen to fine the soil before planting. Uniform and medium-sized (39-75g) tubers of the test variety with sprout lengths of 1.5 to $2.5 \mathrm{~cm}$ (Lung'aho et al., 2007) was planted on ridges with inter-and intra-row spacing of $75 \mathrm{~cm}$ and $30 \mathrm{~cm}$, respectively. The recommend blended NPS and potassium fertilizer rates were applied at planting at the specified rates and placed in banded application methods and urea rates were split applied at planting the rate of $\left(1 / 4 \mathrm{~kg} \mathrm{~N} \mathrm{ha}^{-1}\right)$ and half $\left(1 / 2 \mathrm{~kg} \mathrm{~N} \mathrm{ha}^{-1}\right)$ at 15 days after emergence and one forth (1/4 $\left.\mathrm{kg} \mathrm{Nha}^{-1}\right)$ at mid-stage (at about and 30days) after emergence respectively. On the other hand, weed control were done timely by hoeing. The first, second and third earthlingup were done 15,30 , and 45 days after planting to prevent exposure of the tubers to direct sunlight, promote tuber bulking and ease of harvesting. Haulms were mowed two weeks before harvesting at physiological maturity for reducing skinning and bruising during harvesting and post-harvest handling.

\subsection{Agronomic Data Collection}

Agronomic data were collected from a net plot of two rows and selected plants of the plots. Collected agronomic data includes; Days to $50 \%$ emergence, Days to $90 \%$ maturity, stem number per hill, Plant height $(\mathrm{cm})$, tuber number per hill, Marketable, Unmarketable and Total tuber yield were based on the recommended recording stage and methods

\subsection{Farmers Data Collection}

Farmers' evaluation and selection criteria data were collected on plot basis from the three baby trials i.e., farmers were grouped around each host farmer of the trials. Farmer's evaluation criteria were employed viz. resistant to disease, stem number, tuber size, tuber color, tuber number per hill, tuber eye depth, marketability, and high yielder. A rating scale of 1-5 was used for farmer's criteria. Rating of the performance of variety for a given criteria: $5=$ very good, $4=$ good, $3=$ average, $2=$ poor and $1=$ very poor.

\subsection{Data Analysis}

Field data were analyzed by using Genstat 18 th edition software for the data following the standard procedures outlined by [20]. Comparisons among the treatment means were done using Fisher's protected least significant difference (LSD) test at 5\% level of significant. Farmers' data were subjected to analysis using simple ranking method and then ranked in accordance with the given value [32].

\section{Results and Discussion}

\subsection{Mean Square}

The analysis of variance (ANOVA) for tuber yield and other agronomic variables of six (6) Irish potato varieties planted at Bore on-station as mother trail. The analysis of variance (ANOVA) indicated presence of significant differences at $(\mathrm{P} \leq 0.05$ respectively among the evaluated Irish potato varieties for days to $50 \%$ emergence and flowering, stem number per hill, tuber number per hill, marketable and total tuber yield. However, non-significant difference was observed among the varieties for days to days to $90 \%$ maturity, plant height, tuber weight and unmarketable tuber yield (Table 2).

Table 2. Analysis of Variance for different agronomic parameters of different highland areas of potato Varieties from mother trial.

\begin{tabular}{|c|c|c|c|c|c|c|c|c|c|c|}
\hline \multirow{2}{*}{$\begin{array}{l}\text { Source of } \\
\text { variation }\end{array}$} & \multicolumn{10}{|c|}{ Mean square } \\
\hline & DE (days) & DF (days) & DM (days) & STN (no.) & PH (cm) & TN (no.) & Twt (g) & Myld (tha $\left.{ }^{-1}\right)$ & Umyld (t ha $\left.{ }^{-1}\right)$ & Tyld $\left(\mathrm{t} \mathrm{ha}^{-1}\right)$ \\
\hline $\operatorname{Rep}(2)$ & $0.39 * *$ & $2.39 * *$ & $0.06^{\mathrm{ns}}$ & $3.13 * *$ & $1.24^{\mathrm{ns}}$ & $8.17 * *$ & $30.9^{\text {ns }}$ & $28.44 * *$ & $0.98^{\text {ns }}$ & \\
\hline Varieties $(5)$ & $27.42 * *$ & $106.86^{* *}$ & $2.09^{\mathrm{ns}}$ & $5.58 * *$ & $17.28^{\mathrm{ns}}$ & $15.3 * *$ & $1372.4^{\mathrm{ns}}$ & $275.63 * *$ & $12.45^{\mathrm{ns}}$ & $334.39 * *$ \\
\hline Error(10) & 1.06 & 2.66 & 2.06 & 1.16 & 17.98 & 3.13 & 734.8 & 22.63 & 5.09 & 25.19 \\
\hline
\end{tabular}

$* *=$ highly significant at $\mathrm{P} \leq 0.001 ; *=$ significant at $\mathrm{P} \leq 0.05$; ns $=$ not significant at $\mathrm{P} \geq 0.05$; a Numbers in parentheses are degrees of freedom associated with the corresponding source of variation; DE: Days to Emergence, DF: Days to Flowering, DM: Days to maturity, SN: Stem Number per hill, PH: plant height, TN: Tuber Number per hill, Tw: Tuber Weight, Myld: Marketable yield, Umyld: Unmarketable Yield, Tyld: Total yield

\subsection{Phenology and Growth}

The mean values for the six (6) varieties are shown (Table 3 ). The variation with respect to days to emergence and flowering was ranged from 19 to 27 and 58 to 73 days respectively. Based on the study result, the longest days to $50 \%$ emergence was revealed by Dagim and Bubu (27 and 26.33 days) followed by Belete (24.33 days) respectively. However, early emergence was recorded for varieties Horro (19 days) followed by Gudanie and Jalenie (22 days). In other cases, variety Horro was early flowering variety (58 days) followed by Belete ( 64.67 days). Among the tested varieties, Jalenie was late maturing with 107 days followed by Horro, Belete, 
and Gudanie (106 days) respectively.

The mean values revealed that the highest stem number per hill was recorded by Bubu variety (8.44) followed by variety Belete (6.11) respectively. However, the lowest stem number per hill Jalenie variety (4.44) followed Dagim variety (5.01) respectively. Stem density, which is influenced by genetic makeup, increase tuber yield as stem density increases numbers of tubers, or size of tubers, or both [36]. The longest plant height was exhibited by Horro variety $(66.22 \mathrm{~cm})$ followed by Belete variety $(63.06 \mathrm{~cm})$. However, the shortest plant height was recorded by Dagim variety $(59.83 \mathrm{~cm})$ followed by Gudanie variety (60.06) respectively (Table 3 ). These differences in plant height among the varieties may be caused by plant genetics and the quality of the plant material [14].

Table 3. Mean Value of DE, DF, DM, PH and STN of potato PVS from mother trial in highland areas of Guji zone, during 2019/20.

\begin{tabular}{|c|c|c|c|c|c|}
\hline \multirow{2}{*}{ Varieties } & \multicolumn{5}{|c|}{ Phenology and growth variables } \\
\hline & DE(days) & DF(days) & DM(days) & STN(no.) & PH(cm) \\
\hline Belete & $24.33 b$ & $64.67 b$ & 106 & $6.11 \mathrm{~b}$ & 63.06 \\
\hline Gudanie & $22 \mathrm{c}$ & $71.63 \mathrm{a}$ & 106 & $6 b$ & 60.06 \\
\hline Bubu & $26.33 \mathrm{a}$ & $73 a$ & 104.7 & $8.44 a$ & 60.83 \\
\hline Jalenie & $22 \mathrm{c}$ & $73 a$ & 107 & $4.44 b$ & 62.17 \\
\hline Horro & $19 \mathrm{~d}$ & $58 \mathrm{c}$ & 106 & $5.94 \mathrm{~b}$ & 66.22 \\
\hline Dagim & $27 \mathrm{a}$ & $66 b$ & 105 & $5.01 \mathrm{~b}$ & 59.83 \\
\hline $\mathrm{Cv} \%$ & 4.4 & 2.4 & 1.4 & 17.9 & 6.8 \\
\hline P-Value & 0.001 & 0.001 & 0.46 & 0.017 & 0.49 \\
\hline
\end{tabular}

Mean values sharing the same letter in each column for each factor have no-significant difference at $5 \%$ probability according to Fisher's protected test at $5 \%$ level of significance; CV $(\%)=$ Coefficient of variation, LSD $(5 \%)=$ Least significant difference at $5 \%$ probability.

\subsection{Yield and Yield Components}

Based on agronomic data result indicate that the highest tuber number per hill was recorded from Belete variety (12.33) followed Bubu variety (12.17) where as the lowest tuber number per hill from Dagim variety (6.94) and followed Gudanie variety (7.89) respectively. The highest tuber weight was recorded from Gudanie variety $(130.53 \mathrm{~g})$ followed Jalenie variety $(105.7 \mathrm{~g})$ where as the lowest tuber weight from Dagim variety $(76.05 \mathrm{~g}$ ) and followed Horro and Bubu varieties (78.96g) respectively. Variation among different varieties in the weight of tubers per plant may be due to the genetics, management practices, the seed quality, or the agro-ecological conditions of the experimental sites [14]. Significant variations were revealed among potato varieties number and weight of tubers per plant [2]. The highest marketable tuber yield were obtained from Belete variety $\left(48.17\right.$ tha $\left.^{-1}\right)$ followed by Bubu variety $\left(35.35\right.$ tha $\left.^{-1}\right)$ respectively whereas the lowest marketable tuber yield Dagim variety $\left(18.07\right.$ tha $\left.^{-1}\right)$ followed by Horro variety $\left(32.40\right.$ tha $\left.^{-1}\right)$ was recorded respectively. The highest unmarketable tuber yield were obtained from Gudanie variety $\left(9.53\right.$ tha $\left.^{-1}\right)$ followed by Jalenie variety $\left(8.61\right.$ tha $\left.^{-1}\right)$ respectively whereas the lowest unmarketable tuber yield Dagim variety $\left(4.11\right.$ tha $\left.^{-1}\right)$ followed by Horro variety (5.19tha ${ }^{-1}$ ) was recorded respectively. In other cases, the highest total tuber yield were obtained from Belete variety $\left(54.67 \mathrm{tha}^{-1}\right)$ followed by Gudanie variety $\left(43.84 \mathrm{tha}^{-1}\right)$ respectively whereas the lowest total tuber yield Dagim variety $\left(22.18\right.$ tha $\left.^{-1}\right)$ followed by Horro variety $\left(3.76\right.$ tha $\left.^{-1}\right)$ was recorded respectively (Table 4$)$. Thus, the yield differences between these varieties may be related to their genetic makeup in the efficient utilization of inputs like nutrient as reported by [30]. Significant variations were revealed among potato varieties for no marketable and marketable tuber yields [2]. [29] reported a significant difference in the yields due to genetic makeup of potato varieties.

Table 4. Mean Value of TN, TW, Myld, UMyld and Tyld of potato PVS from mother trial in highland areas of Guji zone, during 2019/20.

\begin{tabular}{|c|c|c|c|c|c|}
\hline \multirow{2}{*}{ Varieties } & \multicolumn{5}{|c|}{ Yield and yield components } \\
\hline & TN(no.) & Twt (g) & Myld (t ha') & Umyld $\left(t h^{-1}\right)$ & Tyld $\left(\mathrm{t} \mathrm{ha}^{-1}\right)$ \\
\hline Belete & $12.33 \mathrm{a}$ & 101.12ab & $48.17 \mathrm{a}$ & $6.49 a$ & $54.67 \mathrm{a}$ \\
\hline Gudanie & $7.89 \mathrm{bc}$ & $130.53 \mathrm{a}$ & $34.3 \mathrm{~b}$ & $9.53 \mathrm{a}$ & $43.84 \mathrm{~b}$ \\
\hline Bubu & $12.17 \mathrm{a}$ & 78.96ab & $35.35 b$ & 7.07ab & $41.76 \mathrm{~b}$ \\
\hline Jalenie & $8.94 \mathrm{abc}$ & $105.7 \mathrm{ab}$ & $32.52 \mathrm{~b}$ & $8.61 \mathrm{a}$ & $41.13 b$ \\
\hline Horro & $10.78 \mathrm{ab}$ & $78.96 \mathrm{ab}$ & $32.40 \mathrm{~b}$ & $5.19 \mathrm{~b}$ & $37.6 b$ \\
\hline Dagim & $6.94 \mathrm{c}$ & $76.05 \mathrm{~b}$ & $18.07 \mathrm{c}$ & $4.11 \mathrm{~b}$ & $22.18 \mathrm{c}$ \\
\hline Lsd (0.05) & 3.22 & 49.31 & 8.65 & 4.1 & 9.13 \\
\hline $\mathrm{Cv} \%$ & 18 & 28.5 & 14.2 & 33 & 12.5 \\
\hline P-Value & 0.016 & 0.19 & 0.001 & 0.12 & 0.001 \\
\hline
\end{tabular}

Mean values sharing the same letter in each column for each factor have no-significant difference at $5 \%$ probability according to Fisher's protected test at $5 \%$ level of significance; CV (\%) = Coefficient of variation, LSD (5\%) = Least significant difference at $5 \%$ probability.

\subsection{Farmer's Variety Selection Criteria's}

In variety selection farmers have a broad knowledge based on their environments, crops and cropping systems built up over many years and do experiments by their own and generate innovations, even though they lack control treatment for comparison and statistical tools to test the hypothesis. Based on this concept, farmers were informed to set criteria for selecting 
best Irish potato variety according to their area before undertaking varietal selection. This was done by making group discussion among the farmers which comprises elders, women and men. After setting the criteria they were informed to prioritize the criteria according to their interest. By doing this, farmers were allowed to select varieties by giving their own value.

Accordingly, resistant to disease, stem number per hill, tuber size, tuber color, tuber number per hill, tuber eye depth, marketability, and high yielder. Based on set criteria, the evaluated varieties were revealed various values by the evaluators (farmers). With this regard, farmers selected/ranked the varieties Gudanie $\left(1^{\text {st }}\right)$, Bubu $\left(2^{\text {nd }}\right)$ and Belete $\left(3^{\text {rd }}\right)$ were showed better performance resistant to disease, highest stem number per hill, marketable tuber size, attractive tuber color, highest tuber number per hill, low tuber eye depth, good for marketability, and highest yielder. However, farmers ranked least Dagim $\left(6^{\text {th }}\right)$ and Horro $\left(5^{\text {th }}\right)$ potato varieties respectively (Table 5). This suggestion is in agreement with that of [35] who report participatory variety selection can effectively be used to identify farmeracceptable varieties and thereby overcome the constraints that cause farmers to grow old or obsolete varieties. This suggestion is consistent also with that of [10] who reported that identification of suitable improved, released cultivars to provide a large 'basket of choices' to farmers. On the other hand, Witcombe et al. [34] reported that PVS is a more rapid and cost-effective way of identifying farmer-preferred cultivars if a suitable choice of cultivars exists.

Hence, Research costs can be reduced and adoption rates increased since farmers participate in variety testing and selection. Moreover, [21] who reported that farmers were actively involved in plant breeding at various levels of the breeding process, the new varieties were successfully adopted. Furthermore, [28] who reported that participatory methods consider the value of farmers knowledge, their preferences, ability and innovation, and their active exchange of information and technologies as it was demonstrated during farmer field school approach.

Table 5. Farmers' preference scores and ranking for baby trial in highland areas of Guji zone, during 2019/20 cropping season.

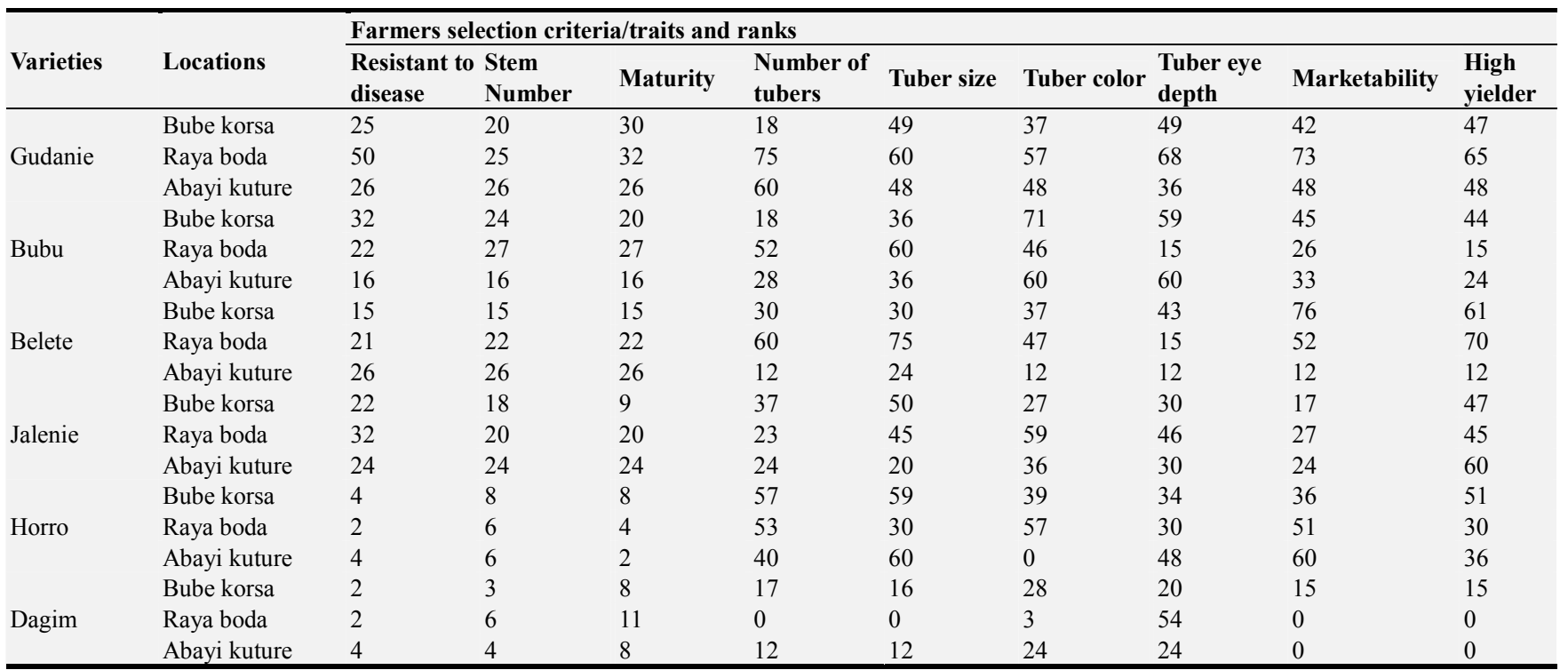

Table 5. Continued.

\begin{tabular}{|c|c|c|c|c|}
\hline Varieties & Locations & Total & Average & Ranks \\
\hline \multirow{3}{*}{ Gudanie } & Bube korsa & \multirow{3}{*}{1188} & \multirow{3}{*}{44} & \multirow{3}{*}{1} \\
\hline & Raya boda & & & \\
\hline & Abayi kuture & & & \\
\hline \multirow{3}{*}{ Bubu } & Bube korsa & \multirow{3}{*}{928} & \multirow{3}{*}{34.38} & \multirow{3}{*}{2} \\
\hline & Raya boda & & & \\
\hline & Abayi kuture & & & \\
\hline \multirow{2}{*}{ Belete } & Bube korsa & \multirow{2}{*}{868} & \multirow{2}{*}{32.5} & \multirow{2}{*}{3} \\
\hline & Abayi kuture & & & \\
\hline \multirow{3}{*}{ Jalenie } & Bube korsa & \multirow{3}{*}{840} & \multirow{3}{*}{31.11} & \multirow{3}{*}{4} \\
\hline & Raya boda & & & \\
\hline & Abayi kuture & & & \\
\hline \multirow{3}{*}{ Horro } & Bube korsa & \multirow{3}{*}{815} & \multirow{3}{*}{30.19} & \multirow{3}{*}{5} \\
\hline & Raya boda & & & \\
\hline & Abayi kuture & & & \\
\hline \multirow[t]{2}{*}{ Dagim } & Raya boda & \multirow[t]{2}{*}{288} & \multirow[t]{2}{*}{10.67} & \multirow[t]{2}{*}{6} \\
\hline & Abayi kuture & & & \\
\hline
\end{tabular}




\section{Conclusion and Recommendation}

In the highland areas of Guji zone an access, well adapted, résistance to late blight and high yielder potato variety is highly limited. In such case, Participatory variety selection is an effective tool in facilitating the adoption, extension and selection of the improved technologies. Furthermore, participatory variety selection is more rapid and cost-effective way of identifying farmer-preferred cultivars if a suitable choice of cultivars exists. The farmers are allowed to participate in selecting appropriate technologies by employing their own indigenous knowledge. As the result, the current study was also verified that farmers were able to participate in selecting improved Irish potato varieties through employing their own selection criteria. Improved potato varieties through employing their own selection criteria in order to verified technologies and solve the potato grower problems in short period of time. Therefore, two improved potato varieties i.e. Gudanie and Bubu are selected based on agronomic data results, farmer's preference and recommended for highland areas of Guji zone.

\section{References}

[1] Adane H., Meuwissen, M. P., Tesfaye, A., Lommen, W. J., Lansink, A. O., Tsegaye, A., \& Struik, P. C. (2010). Analysis of seed potato systems in Ethiopia. American journal of potato research, 87 (6), 537-552.

[2] Addis S, Dessalegn R, Wakene, T. 2017. Irish Potato (Solanum tuberosum L.) variety evaluation at Bule Hora District of Borena Zone. Global Journal of Science Frontier Research: D Agriculture and Veterinary Volume 17 (2).

[3] Arega A. 2018. Response of Potato (Solanum tuberosum L.) to Blended NPS and Potassium fertilizers at Bore, Southern Ethiopia. M.Sc. Thesis. Haramaya University, Ethiopia, pp. 20-30. of Agriculture, Haramaya University. 86p.

[4] Bekele K, Eshetu B (2008) Potato Disease Management. Root and Tuber Crops the Untapped Resources. In: Gebremedhin W, Endale G, et al. (Eds.), Ethiopian Institte of Agricultural Research, Ethiopia, pp. 79-95.

[5] Bellon, M. R. 1996b. The dynamics of crop intraspecific diversity: a conceptual framework at the farmer level. Economic Botany 50 (1): 26-39.

[6] Bereke Tsehai T. 1994. The utilization of true potato seed (TPS) as an alternative method of potato production. Ph.D. thesis, Wageningen, The Netherlands.

[7] BoARDO (Bore Agriculture and Rural Development Office). 2015. Agriculture Report of Bore District.

[8] Bradshaw J, Gebhardet C., Goves F., Mackerron K. L., Mark A., Taylor M. and Ross, H. 2007. Potato biology and bitechnology advances and perspectives.

[9] Ceccarelli S, Grando S, Booth RH., 1996. International breeding programmes and resourcepoor farmers: crop improvement in difficult environments. In: Eyzaguirre P,
Iwanaga M (eds.). Participatory plant breeding. Proceeding of a workshop on participatory plant breeding, 26-29 July 1995, Wageningen, The Netherlands. IPGRI, Italy, pp 99-116.

[10] Chambers, R. 1989. Institutions and practical change: reversals, institutions and change. pp. 181-195. In, R. Chambers, A. Pacey, L. A. Thrupp, eds. Farmer first. London: Intermediate Technology Publications.

[11] Crissman CC, Crissman LM, Carli C (1993). Seed potato systems in Kenya: a case study. Lima: CIP.

[12] CSA (Central Statistical Agency). 2019. Report On Area and Production of Major Crops. Agricultural sample survey Addis Ababa Statistical Bulletin Volume 1 pp: 584, 14-68.

[13] Devaux, A., P. Kromann, O. Ortiz. 2014. Potatoes for sustainable global food security. Potato Research.

[14] Eaton TE, Azad AK, Kabir H, Siddiq AB. 2017. Evaluation of Six Modern Varieties of Potatoes for Yield, Plant Growth Parameters and Resistance to Insects and Diseases. Agricultural Science; 8 (11): 1315-26.

[15] Eskin, N. A. 1989. Quality and Preservation of Vegetables. pp. 2-11. CRS press, Inc. Bocaraton, Florida.

[16] FAO (Food and Agriculture Organization). 2014. Potato world Production consumption. International year of the Potato. USA. Rome, Italy.

[17] Fekadu, A., Y. Petros and H. Zelleke, 2013. Genetic variability and association between agronomic characters in some potato (Solanum tuberosum L.) genotypes in SNNPRS, Ethiopia. Int. J. Biodiversity. Conserv.

[18] Gebremedhin W., Endale G., Kiflu B. 2013. National potato research program report. Ethiopian Agricultural Research Organization, Holetta Agricultural Research Center. pp. 125.

[19] Gildemacher, P., Kaguongo, W., Ortiz, O., Tesfaye, A., Woldegiorgis, G., Wagoire, W., Kakuhenzire, R., Kinyae, P., Nyongesa, M. and Struik, P. 2009. 'Improving Potato Production in Kenya, Uganda and Ethiopia: A System Diagnosis'. American Potato Journal. 173-205.

[20] Gomez, K. A. and Gomez, A. A. 1984. Statistical Procedures for Agricultural Research, $2^{\text {nd }}$ edition, John Wiley and Sons, New York, p. 680.

[21] Graham, T., E. Van de Fliert, and D. Campilan. 2001. "What happened to participatory research at the International Potato Center?" Agriculture and Human Values 18: 429-446.

[22] Haverkort, A. J., P. C. Struik, R. G. F. Visser, and E. Jacobse. E. 2009. Applied biotechnology to combat late blight in potato caused by Phytophthora infestans. Potato Research 52: 249264.

[23] Hirpa, A., M. P. M. Meuwissen, A. Tesfaye, W. J. M. Lommen, A. O. Lansink, A. Tsegaye, and P. C. Struick. 2010. Analysis of seed potato systems in Ethiopia. American Journal of Potato Research 87: 537-552.

[24] Lisinska, G., and W. Leszcynski. 1989. Potato science and technology. Elsevier, London.

[25] Lung'aho, C., Lemaga, B., Nyongesa, M., Gildermacher, P., Kinyale, P., Demo, P., Kabira, J. 2007. Commercial seed potato production in eastern and central Africa. Kenya Agriculture Institute, 140p. 
[26] Meaza Hafiz. 2015. Participatory Variety Selection And Variability Of Potato (Solanum tuberosum L.) Varieties At Jimma Zonne, Southwest Ethiopia, Msc Thesis Work At Jimma University Pp. 1-87.

[27] MoANR (Ministry of Agriculture and Natural Resources). 2016 Plant Variety Release, Protection and Seed Quality Control Directorate. Crop Variety Register Issue No. 19 pp: 1-318.

[28] Ortiz O., G. Frias, R. Ho., H Cisneros, R. Nelson, R. Castillo, R. Orrego, W. Pradel, and J. Alcazar. 2008. Organizational learning through participatory research: CIP and Care in Peru. Agriculture and Human Values 25: 419-431.

[29] Tapiwa R. Mpemba. 2016. Evaluation of new Irish Potato (Solanum tuberosum L.) varieties for yield potential in Zimbabwe. BSc thesis, Midlands State University, Faculty of Natural Resources Management and Agriculture).

[30] Tisdale SL, Nelson W, Beaton JD, Havlin JL. 1995. Soil fertility and fertilizers. $5^{\text {th }}$ edition. Macmillan, USA.

[31] Wakene Tigre, Walelign Worku, Wassie Haile. 2014. Effects of Nitrogen and Phosphorus Fertilizer Levels on Growth and Development of Barley (Hordeum vulgare L.) at Bore District,
Southern Oromia, Ethiopia. American Journal of Life Sciences. Vol. 2, No. 5, pp. 260-266.

[32] Walter SDB, Marja HT. 2007. Participatory Tools Working with Crops, Varieties and Seeds. Wageningen University and Research Center.

[33] Wiersema, S. G., and P. C. Struik. 1999. Seed potato technology, 383. Wageningen: Wageningen Pers.

[34] Witcombe, J. R., Joshi, A., Joshi, K. D. and Sthapit, B. R. 2008. Farmer Participatory Crop Improvement. I. Varietal Selection and Breeding Methods and Their Impact on Biodiversity. Experimental Agriculture, 32 (04), p. 445.

[35] Witcombe, J. R, A. Joshi, K. D. Joshi \& B. R. Sthapit. 1996. Farmers participatory crop improvement. I. varietal selection and breeding methods and their impacts on biodiversity. Expl Agric 32: 445-460.

[36] Zelalem A, Tekalign T, Nigussie D. 2009. Response of potato (Solanum tuberosum L.) to different rates of nitrogen and phosphorus fertilization on vertisols at DebreBerhan, in the central highlands of Ethiopia. African Journal of Plant Science 3 (2): 16-24. 